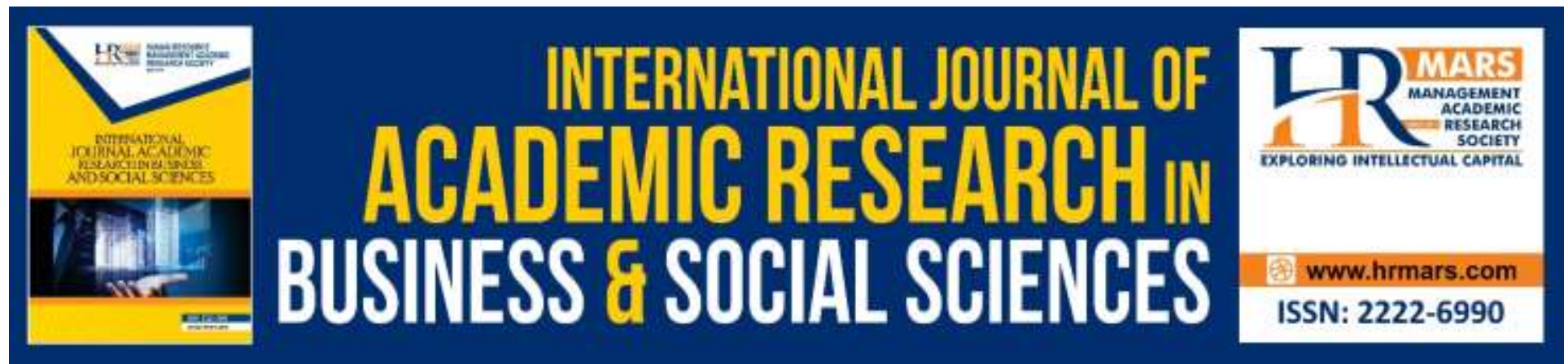

\title{
A Woman in Islam Perspective
}

\section{Nur Shamimi Binti Azman, Wan Khairul Aiman Wan Mokhtar, Asma Afifah Rashid, Eusoff Amiruddin, Ahmad Safwan Jamaludin}

To Link this Article: http://dx.doi.org/10.6007/IJARBSS/v9-i11/6585

DOI: 10.6007/IJARBSS/v9-i11/6585

Received: 12 October 2019, Revised: 30 October 2019, Accepted: 04 November 2019

Published Online: 30 November 2019

In-Text Citation: (Azman et al, 2019)

To Cite this Article: Azman, N. S. B., Mokhtar, W. K. A. W., Rashid, A. A., Amiruddin, E., Jamaludin, A. S. (2019). A Woman in Islam Perspective. International Journal of Academic Research in Business and Social Sciences, 9(11), 640-646.

Copyright: (C) 2019 The Author(s)

Published by Human Resource Management Academic Research Society (www.hrmars.com)

This article is published under the Creative Commons Attribution (CC BY 4.0) license. Anyone may reproduce, distribute, translate and create derivative works of this article (for both commercial and non-commercial purposes), subject to full attribution to the original publication and authors. The full terms of this license may be seen at: http://creativecommons.org/licences/by/4.0/legalcode

Vol. 9, No. 11, 2019, Pg. 640 - 646

http://hrmars.com/index.php/pages/detail/IJARBSS

JOURNAL HOMEPAGE

Full Terms \& Conditions of access and use can be found at http://hrmars.com/index.php/pages/detail/publication-ethics 


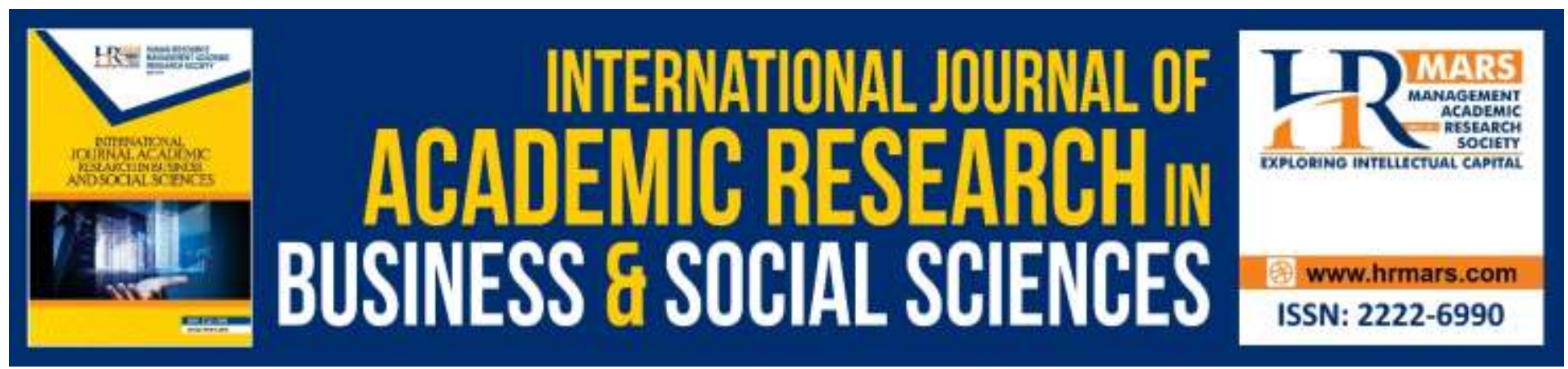

\title{
A Woman in Islam Perspective
}

\author{
Nur Shamimi Binti Azman, Wan Khairul Aiman Wan Mokhtar, \\ Asma Afifah Rashid,Eusoff Amiruddin, Ahmad Safwan Jamaludin \\ Universiti Sultan Zainal Abidin (UniSZA), Gong Badak Campus, 21300, Kuala Nerus, Terengganu, \\ Malaysia
}

\begin{abstract}
The main purpose of this research is to acknowledge the rights of woman in Islam. The rights of a woman had been introduced to the world after the presence of Islam in the society. The religion of Islam really prioritizes the status of a woman since the woman before the presence of Islam is been treating just like a thing that can be owned easily by every man and also been treated no better than a slave. Even in this current year, there are a lot of people that still do not know about the right or freedom that every woman has in their hands because of this reason there are many cases about the abuses of women and children been reported every year in various countries. Hence, the question that often arise among the community because of this issue is what are the rights of women have as a daughter, wife and mother? The main objective for this study is to determine the rights of woman in Islam. This research had used a few methods which are library research and analysis of documents to complete this study. The result of this research, there a lot of rights about a woman but the rights that had been included in this study are the rights as mother, rights regarding marriage, rights as wife, and rights regarding divorce.
\end{abstract}

Keywords: Rights of Woman, Islam, Mother, Marriage, Wife, and Divorce

\section{Introduction}

The religion of Islam really prioritizes the status of a woman since the woman before the presence of Islam is been treating just like a thing that can be owned easily by every man and also been treated no better than a slave. Even in this current year, there are a lot of people that still do not know about the right or freedom that every woman has in their hands because of this reason there are many cases about the abuses of women and children been reported every year in various countries.

The question that had been a hot topic in this issue is what are the rights of women have as a daughter, wife and mother? This question became the foundation for this conductor research. The discussion about this research is to study about the rights of women in Islam and how the rights can be a big help for them to been treated equally with the men gender. 


\section{Research Methodology}

In order to produce a research, then a research requires from its methodology. This research was applied a methodology in order to complete a study from its way properly and comprehensively (Mokhtar, 2017; Razak, Johari, Mahmud, Zubir, \& Johan, 2018).

This research had used a qualitative methods. To accomplish the study objectives, library research was been applied. The data are collected from books, journals and articles were related to the study. Data has been analysed and the conclusion was made from the analysis (Mokhtar, 2017; Umaru, Aguda, Davies, 2018).

\section{Findings and Research Discussion}

"Behind every great man, there is a great woman". This quote is very familiar to us in this day. And it has a straightforward literal meaning which is it shows that the great woman is often ignored or taken for granted. Obviously, this situation commonly happens in the good old days when the community had a shallow thinking style and refused to accept other cultures which have a modern thinking style and wide knowledge than them. Fortunately, people nowadays had given the same priority and equality to every person regardless of gender differences. Especially, the rights toward woman.

Furthermore, the issue of woman's rights received much attention in western and western-like societies for the past number of decades. The first person who was acknowledged about the rights of women who had always been forced to live in undignified life is prophet Muhammad (S.A.W), then the other countries began to follow prophet Muhammad (S.A.W) by respecting and giving the rights to every woman (Al-Kahtany, 2009). Before that, the woman normally been treated by inequitable treatment than the male. For example, the female in preIslamic civilization or for the period of Jahiliyah always been treated poorly. The women were treated no better than a goods. Not only were they enslaved, but they could also be inherited as a possession. If her husband is passed away, the wife was forced to marry the elder son or other relatives to be married to them without requires the bride permission and with no wedding money and gift for them, or tie the knot them to others, or keeping out them from marriage at all (Engineer, 1992; Moschou, 2018).

In addition, the Arabs in Jahiliyah used to kill or bury their daughters alive. This indicates that the women had been treated unfair since the beginning of their live. The innocent little girls were killed cruelly without a reasonable reason. How the parents could in this era are willing to kill their own daughters? The question like this always been a big question to the all of the normal person who are living in this 21st century. The reasons why they are willing to kill their own flesh and blood are cheap and unreasonable, for example, afraid of becoming the poor and decrease of provision. The other unreasonable reasons are afraid of humiliation only because getting a daughter as the child (Khan, 2013). When the era of Islam had coming, the sake of daughter or woman had been giving the priority. A lot of sayings from the prophet Muhammad S.A.W in which he has guaranteed an abundant of good return from Allah S.W.T if they had treated the female kids gently and respectful. "If the parent has a daughter and does not put her six feet under the 
ground alive, or kill her, or he is not biased towards the son compare to the daughter, then Allah will be giving him a Heaven as the reward." Also, based on Aishah (May Allah have mercy on her), the prophet Muhammad S.A.W said, "If the person was under agony for providing the dignified life for these girls and taken care of them properly, the girls will be a prevention for him from being taken into the Hell" (Ahmad, 2003).

Furthermore, there are many rights for the women in Islam had been introduced since that. The rights were divided into several categories and there are a lot of rights about woman to be discussed, but there only a few types of rights to be explained in this study, which are the rights as mother, rights regarding marriage, rights as wife, and rights regarding divorce. Firstly, the rights as mother for a woman are dutifulness and respect. A mother should obtain the dutifulness and respect from her children such as the children must obey every order from his or her mother as long as the order not against the shari'ah (Ahmed, 2011). Then, the right of guardianship over her offspring. A woman who became a single mother after been divorced has the more chances in taking care of the offspring rather than her ex-husband because of stuffs such as feeding and education as long as she does not marry anyone (Rafiq, 2014). Furthermore, the right of shareholder in the inheritance of the children. If the children of her had passed away but her children have a son, then the mother will get one sixth of the inheritance. But, if her children do not have a son and the parents will be the heir. So, the mother will be getting one third from the inheritance. In addition, based on the Al-Hadith, a mother has a higher place than a father in respect and obedience of the children (Zubair, Khattak, Hidayat-ur-Rehman, \& Khan, 2014).

The rights to marry also one of the rights as a woman in Islam. The word of marriage in Arabic is Nikah and it also indicate a contract and it had several conditions that must be follow by the man as the groom and husband for the woman as his wife as stated in the Al - Quran, "By what means should you obtain it back when one of you had reached for you and he or she have engaged a solid promise from you?" (QS 4:21). And the other greatest verse in the Al-Quran about marriage is "and of His signs is this: Allah produced a partners for you from your own, so that you can discover a nice break in your mate and He commanded an affection and sympathy from the both of you" (QS 30: 21). This displayed that the Al-Quran indicates that the meaning of wedding is a sharing between the two soulmates which is a husband and wife. One of the right for the woman who going to be a bride is the freedom to select the man who will be her husband so that he gets to know what her soon to be husband will look like and she will get the better knowledge about what kind of person is her future husband with no force from her father or anyone. Furthermore, the soon to be bride also has the chance to protest at the court if the anyone has forced her to get married without her wills and consent (Ahmad, 2003). But this situation was totally differences in the women who were living in the Jahiliyyah era, they were married with no consent from them because their opinion is not important since the marriage agreement only involves the man who will be the groom and the bride's father or her guardian only during the decision making. They were treated a little better than a slave if they were married (al-Faruqi, 1988). 
The rights of woman as a wife in Islam, the woman as a legal spouse for her husband has financial rights over him such as dowry or wedding money and spending. The dowry basically means as a symbol of protection, affection, and respect for the wife (Mutairi, 2004). First and foremost, the husband must be giving his wife the dowry as a free gift during the wedding. But, if the wife refuses to accept the dower or she want to share the dower on her own pleasure with him, then he can take the dowry and enjoy it with right good cheer (Chaudhry, 1991). Based on the opinion of the intellectuals of Islam, they were agreed that it is compulsory for men to use their money to provide necessary things for their beloved wives such as clothing, house, food and others. On the other hand, the woman as the wife need to ensure she is accessible to her husband. In the case of the wife is ignoring and preventing her husband needs, so the wife does not have any right in that spending that was providing from her husband. The other right for the woman as a wife in non-financial aspect is the husband need to provide the good care for the wife. For example, the husband must be giving the kindness and gentleness toward her because every woman deserved this kind of treatment. Even in Holy of Al-Quran had mentioned about this;

"Males are the guardians and maintainers of females because Allah has setting up the males as much stronger than the females, so that they can backing up them from their means" (Qur'an 4:34).

Furthermore, the right of woman as the wife also been mentioned not only by the Holy of AlQuran but prophet Muhammad S.A.W prioritize about this matter too. So, the husband must be giving the good and best treatment for his wife. Allah says:

"... But take care of the wife with thoughtfulness, and if the husband dislikes the wife, this also means that he dislikes what had Allah positioned as the great thing." (QS 4:19).

The Prophet Muhammad S.A.W also mentioned, "The best impeccable followers are the greatest in management and the preeminent of the husband is the one who are the finest to his wife." (Ibn Hanbal, No, 7396) (Badawi, n.d.).

Besides that, the other rights for woman is the rights regarding divorce. The presence of Islam not only bring up the status of women but also improve the solution for the divorcement. In addition, the Al-Quran also mentioned about the equal rights between males and females in divorce procedures, "If a wife afraid of savage or unfaithful from her husband then it is not fault on a spouse if she set up an agreeable solution between them." (QS 4:128) (al-Faruqi, 1988). In other word, the wife can also have the authority of divorce as a trusted right. Basically, the Islamic law has the perspective about a wife does not have the inherent natural right of divorce, but in a particular conditions of right in divorce that had been inserted in the wedding agreement, the wife can have the right regarding the separation or divorce with her husband if the husband break the mutual agreement contract that had been made before the wedding (Mutahhari, 1980). Last but not least, the wife also can have the right in divorce through a court if the husband has a certain unfortunate conditions which are abandonment, infertility, the husband failed to offered the enough support, physical or mental ill-treatment, severe physical or mental illness, apostasy and proved immoral self-indulgence (al-Faruqi, 1988). 


\section{Conclusion}

In the nutshell, this research had determined the rights of a woman in Islam which are the rights as mother, rights regarding marriage, rights as wife, and rights regarding divorce. These rights obviously can be illustrated after the presence of Islam. Islam not only bring up the light to the people to be a pious servant to our greatest creator, Allah S.A.W but also bring up the dignity of a woman that had been underestimate for so long by an irresponsible man.

\section{Acknowledgement}

This paper is founded on the research project of the Fundamental Research Grant Scheme FRGS/1/2018/SSI03/UNISZA/02/2 (Project No: RR279). Special appreciation is owed to Ministry of Higher Education Malaysia (MOHE) and Universiti Sultan Zainal Abidin (UniSZA) for sponsoring and supporting this research.

\section{Corresponding Author}

Wan Khairul Aiman bin Wan Mokhtar (Ph.D), Senior Lecturer, Universiti Sultan Zainal Abidin (UniSZA), Gong Badak Campus, 21300 Kuala Nerus.

E-mail: wk_aiman@yahoo.com / wkhairulaiman@unisza.edu.my

\section{References}

Ahmad, N. (2003). Women in Islam Volume 1. A.P.H. Publishing.

Ahmed, M. E. (2011). The Rights of Parents. Hyderabad: Al-Ather Islamic Centre.

Al-Faruqi, L. (1988). Women Muslim Society and Islam. Unicef Australia: American Trust Publications.

Al-Kahtany, A. (2009). Women's Rights a Historical Perspective. The Islamic Educational Center. Al-Mutairi, M. (2004). A Study of the Wife's Rights in Islamic Fiqh. University of Birmingham.

Badawi, J. A. (n.d.). The Position of Woman in Islam. (n.p.).

Chaudhry, M. S. (1991). Women's rights in Islam. New Delhi: Adam Publishers \& Distributors.

Engineer, A. A. (1992). The Rights of Women in Islam. IBS Buku Sdn. Bhd.

Khan, A. (2013). Human Ignorance (Jahiliyyah): Past \& Present. Peshawar City: Govt. College of Management Sciences.

Khan, M. A. (2014). The Laws of Inheritance in Islam. (n.p.).

Mokhtar, W. K. A. W. (2017). Concept Al-Hadīth Al-Mawḍū'iy as A Method of Collecting and Analyzing Research's Data. International Journal of Academic Research in Business and Social Sciences, 7(2), 536-542.

Moschou, K. (2018). Views of Primary School Principals on Conflict within the School Unit. Multilingual Academic Journal of Education and Social Sciences, 6(1), 163-181 (in Greek).

Rafiq, A. (2014). Child Custody in Classical Islamic Law and Laws of Contemporary Muslim World (An Analysis). University Pakistan.

Razak, N. H. A., Johari, K. S. K., Mahmud, M. I., Zubir, N. M., \& Johan, S. (2018). Module of Cognitive Behavior Play Therapy on Decision Making Skills and Resilience Enhancement 
(CBPT Module). International Journal of Academic Research in Progressive Education and Development, 7(4), 179-199.

Umaru, H., Aguda, N. A., Davies, N. O. (2018). The Effects of Exchange Rate Volatility on Economic Growth of West African English-Speaking Countries, International Journal of Academic Research in Accounting, Finance and Management Sciences 8 (4): 131-143.

Zubair, M., Khattak, S., Hidayat-ur-Rehman, Mutahhari. (1980). The Rights of Women in Islam. Islamic Republic of Iran. Chapter - IV: The Rights of Women in Islam. (n.p.). 